\title{
INFLUENCE OF PROTECTED AND UNPROTECTED FAT SUPPLEMENTATION ON MILK YIELD AND COMPOSITION IN POSTPARTUM PERIOD OF BUFFALOES. \\ Baiomy,A.A. ${ }^{1}$ and M. N. E. Hamad ${ }^{2}$ \\ ${ }^{1}$ Animal production Dept., Faculty of Agric. "Qena", South Valley Univ. \\ ${ }^{2}$ Food science and Dairy Dept., Fac. of Agric. "Qena", South Vally Univ.
}

\begin{abstract}
Thirty lactating buffaloes were divided into three groups (10 animals each), first group; fed on unsupplemented control ration (CG), second group (G2) fed on ration supplemented with (600gm Alpha Mega-fat powder/head/day)and third group (G3) fed on ration supplemented with $(600 \mathrm{gm}$ soybean oil /head/day). The obtained results revealed that there are significant $(p<0.05)$ increase in milk yield, Fat corrected milk (FCM), total solids and fat contents as compared with control group. It was also noticed that supplementing rations with Alpha Mega-fat (G2) per buffalo daily improved the fatty acids (C18 "Stearic acid", C18:1 "Oleic acid" and C20 "Arachinic acid") significantly $(p<0.05)$, whereas, unsupplementing rations with control (CG) increased the fatty acids (C12 "lauric acid" and C14 "myristic acid") significantly $(p<0.05)$, when compared with the corresponding groups.Addition of both Alpha Mega-fat and soybean oil to ration of dairy buffaloes improved production efficiency ((kg7\%FCM $/ 1 \mathrm{~kg}$ SVP for milk) and Feed conversion (kg 7\%FCM $/ 1 \mathrm{~kg}$ SVP for milk) significantly $(p<0.05)$. The results of the present study suggested on economic basis that, supplementation of Alpha Mega-fat to lactating Buffaloes generated a fourfold return on investment through a $15.26 \%$ improvement in production efficiency, feed conversion and milk yields in 70 days trial.
\end{abstract}

Keyward : Yield of milk - Alpha Mega-fat - soybean oil - Free Fatty acids buffaloes.

\section{INTRODUCTION}

Buffalo is the major source for milk in Egypt as it contributes more than $50 \%$ of the annual milk production in Egypt (Agriculture economic institute, 1997). Buffaloes milk is preferred by the Egyptian consumer for its richness and sensory attributes. Therefore, buffalo's milk gets almost double the price of cow's milk in the local market. Generally, there is an increasing demand for buffalo milk in Egypt. However buffaloes are low milk producers compared to the dairy breeds of cows being raised in Egypt. Breeding and genetic selection, failed to increase much the amount of milk produced by buffaloes as it did for cows.(Helal and Lasheen, 2008). Recently years, the increased genetic merit of dairy cows has led to higher supplementation of cereal grains. However, feeding large amounts of cereal grains can decrease ruminal $\mathrm{pH}$, reduce ruminal fiber digestibility, decrease the acetate/propionate ratio, increase the risk of ruminal acidosis, and reduce milk fat concentration (Bargo et al., 2003). To overcome these problems and to increase energy intake, interest has increased in feeding supplemental fat to dairy cows (Schroeder et al., 2002). Theoretically, supplementation of fat could have some of the following advantages: 
1 - Increase the energy density of the diet because fat contains three times more net energy of lactation than protein- and carbohydrate-rich feeds (Palmquist, 1984).

2 - Improve the energetic efficiency, because reduced loss of energy as heat, methane, and urine may be expected (Jenkins, 1993), and because the dietary fatty acids (FA) are incorporated directly into milk fat by the mammary gland (Garnsworthy, 1997).

3 - Reduce the risk of rumen acidosis and a decrease in milk fat percent induced by feeding high levels of cereal grains in the diet (Palmquist, 1988).

4 - Alter the milk fat composition by increasing long chain unsaturated FA, conjugated linoleic acids (CLA), and decreasing saturated FA to obtain dairy products of more beneficial for human health (Parodi, 1999).

The feeding of vegetable oils protected with a protein coat insoluble in the rumen as a means of preventing ruminal biohydrogenation was first reported by (Scott et al. 1970 and 1971). Although the inclusion of supplemental fat is common in total mixed ration (TMR) based systems, information on fat supplementation for dairy buffaloes is limited. Therefore, the present work was carried out to differentiate the effect of addition of protected and unprotected fat to the diets of dairy buffaloes on their quantiqualitative milk production as well as body performance.

\section{MATERIAL AND METHODS}

\section{Fat supplements:}

Alpha Mega-fat ${ }^{\circledR}$ : Protected fat was calcium salt of long chain fatty acids (Calcium Soaps of palm fatty acids). Alpha Mega-fat obtained from Alpha Chemical, Egypt.

Soya bean oil (ACETATO DE ETILA ${ }^{\circledR}$ ): imported from Indzstria Brasiliera, Brazil.

\section{Feeding and management:}

Thirty lactating buffaloes (aged 3-6 years, average body weight $563 \pm$ $19.83 \mathrm{~kg}$ ) were monitored during the period from April to June 2008, during their high lactation period shortly after peak to carry out the experiment. Animals were kept in open yards belonging to Animal Production Experimental Farm, Faculty of Agriculture, South Valley University. Animals were provided (at 8.00 a.m and 5.00 p.m.) diet consisted of a concentrate pelted mixture (55\% starch value and $15 \%$ crude protein) according to their live body weight and level of milk production. Beside the concentrate mixture, animals were fed rice straw. Water was available all day and minerals were supplied in salt licking blocks. Animals were adopted the double daily mechanical milking at 5.0 a.m. and 4.00 p.m. Thirty dairy buffaloes at peak of lactation are divided into three groups (10 animals each): Control (CG): received only 100 of NRC nutrient allowances without fat for 6 weeks after parturition (2-6 weeks of lactation period). G2: received 100 of NRC nutrient allowances with added protected fat (Alpha Mega-fat $600 \mathrm{~g} /$ head / day) for 6 weeks after parturition. G3: received 100 of NRC nutrient allowances with 
added unprotected fat (soybean oil $600 \mathrm{~g} /$ head / day) for 6 weeks after parturition.

Body weight of animals was recorded at the beginning and at the end of the experiment. The animals were also monitored for the occurrence of mastitis, such animal was excluded from the trial.

\section{Sampling:-}

Representative samples of the feedstuffs used were analyzed for crude protein (CP), crude fiber (CF), ether extract (EE), Nitrogen Free Extract (NFE) and ash according to A.O.A.C. (2000). Individual milk samples, consisting of proportional volumes of morning and evening milk, were collected in order to evaluate milk composition ( $5 \mathrm{ml} / \mathrm{kg}$ of produced milk). A composed milk sample of each animal was analyzed weekly. Fat content was determined by the standard Gerber method according to the British Standard Institute (1962). Protein content of milk was evaluated by Micro Kjeldahl technique (A.O.A.C, 1990). Total solids (TS) content of milk was determined gravimetrically using the method by Oser (1965). Solid not fat (SNF) was calculated by the difference (T.S\% - fat\%). Milk yield was corrected to $7 \%$ fat for buffaloes. 1962).

$7 \% \mathrm{FCM}=0.265 \times$ milk yield $+10.5 \times$ fat yield (Raafat and Saleh

Actual milk production, FCM (4\%fat), milk fat\%, energy $/ \mathrm{kg}$ milk production and milk fat composition by using (G.L.C) $\left(\mathrm{C}_{10}-\mathrm{C}_{14}-\mathrm{C}_{16}-\mathrm{C}_{18}-\right.$ $\mathrm{C}_{22}$ ) were determined according to Hamzawi and Shahin (1986).

Feed efficiency:

It was assumed in the present investigation that the nutritive value of buffaloes milk is $23.8 \%$ starch value (SV) containing 3.8 digestible protein (DP). Gains formula (1928) for the coefficient was used for calculating the gross and net energy efficiency of feed utilized for milk production. The following formulas were used:

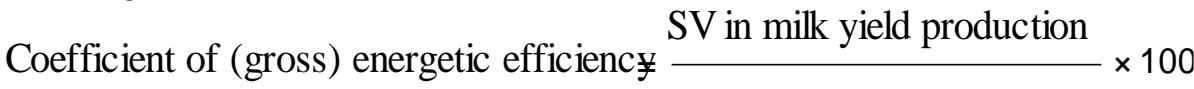

$\mathrm{SV}$ in total feed consumed

Coefficient of (net) energetic efficiency $=\frac{\text { SV in milk yield production }}{\mathrm{SV} \text { in total feed consumed above maintenance }} \times 100$

Statistical analysis of the data :

Data were statistically analyzed according to the General Linear Model (G.L.M) and the differences between means were detected by Duncan`s Multiple Range Test, SAS (1998).

\section{RESULTS AND DISCUSSION}

Feedstuffs quality and diet characteristics: Tables 1 and 2 shows the mean chemical composition of the dietary constituents fed during the experimental periods. The two fat sources used in the experimental diets were characterized by different fatty acid composition, as shown in Table 3. 
Table (1): Mean chemical composition (\% of dry matter ) of feed used.

\begin{tabular}{|c|c|c|c|c|c|c|}
\hline \multirow{2}{*}{ Items } & \multirow{2}{*}{ Moisture } & \multicolumn{5}{|c|}{ Dry matter } \\
\cline { 3 - 7 } & & C.P & E.E & C.F & NFE & Ash \\
\hline Rice straw & 93.40 & 4.40 & 1.80 & 41.24 & 37.89 & 14.67 \\
\hline Concentrate mix. & 90.40 & 15.60 & 2.20 & 19.35 & 51.24 & 11.60 \\
\hline C.P:- Crude protein & \multicolumn{4}{|c|}{ C.F:- Crude Fiber } \\
E.E:- Ether Extract & \multicolumn{4}{|c|}{ NFE - Nitrogen Free Extract }
\end{tabular}

Table(2): Ingredients and composition of Alpha Mega-fat

\begin{tabular}{|c|c|}
\hline \multicolumn{2}{|c|}{ Supplementation. } \\
\hline Ingredients & $\%$ \\
\hline Fatty acids & 84 \\
Calcium & 9 \\
No- soaps & 4 \\
Moisture & 3 \\
\hline Total & $100 \%$ \\
\hline
\end{tabular}

Table (3) Mean individual and total fatty acids intake.

\begin{tabular}{|c|c|c|}
\hline Fatty acid & soybean oil & Alpha Megafat (Palm oil) \\
\hline Palmitic (16:0) & 12 & 42 \\
\hline stearic (18:0) & 4 & 4 \\
\hline Oleic (18:1, $\mathbf{n}-\mathbf{9})$ & 23 & 43 \\
\hline linoleic $(\mathbf{1 8 : 2 , \mathbf { n } - 6 )}$ & 52 & 8 \\
\hline linlenic (18:3, $\mathbf{n}-\mathbf{3})$ & 7 & 1 \\
\hline Others & 2 & 2 \\
\hline
\end{tabular}

\section{Milk yield and its composition :}

Milk yields and composition of milk are indicated in Table 4. Data revealed that the addition of Alpha Mega-fat significantly $(p<0.05)$ increased milk yield, fat corrected milk, fat and total solids of buffaloes milk, on the other side, protein, solid not fat and ash non significantly changed, when compared with control group. Meanwhile, data obtained due to the addition of soybean oil significantly $(p<0.05)$ increased milk yield, fat corrected milk and total solids of Buffaloes milk when compared with control group, finally, comparison of both treated groups with each other evoked non significant change. (Table 4). Total milk and fat yield increased by both experimental diets $(P<0.05)$, reflecting both increased milk production and fat percent. Milk crude protein content unchanged by the experimental diets $(P<0.05)$.

Fortunately our data came in agreement with those reported by Schroeder et al. (2004), who stated that a higher milk response was observed with saturated fat vs. unsaturated fat supplements due to an inhibition on de novo fat synthesis in the mammary gland. This was achieved by feeding the animals protected fat better than soybean oil, which contained up to $85 \%$ unsaturated fatty acids (Kononoff et al. 2005). It has been suggested that the maximum milk production response to fat supplementation is not achieved until cows are in a positive energy balance (Skaar et al., 1989 and Davison et al., 1991). This observation may probably explain the higher increase in milk yield associated with such lactation period in dairy buffaloes in our trial. The 
unexpected change in milk protein with the unprotected diet may reflect the apparently rapid breakdown of the soluble protein by rumen microorganisms, with subsequent loss of ammonia (Mattos and Palmquist, 1974). Also, microbial synthesis is improved by lipid supplementation generally exhibit a drop in protozoa1 ruminal concentration .It is well known that the decrease in protozoa results in a lesser engulfment of bacteria and shortens the nitrogen cycle in the rumen (Doreau and, Ferlay, 1995). Generally, any increase even non significant statistically in any milk component especially fat may be of concern from commercial point of view.

Tables (4): Means ( \pm SE) for milk yield and milk components of buffaloes as affected by supplementation of protected and unprotected fat in the ration.

\begin{tabular}{|c|c|c|c|}
\hline Item & $\mathbf{C G}$ & G2 & G3 \\
\hline Milk yield & $6.25 \square 0.11^{b}$ & $7.05 \square 0.17^{a}$ & $7.15 \square 0.17^{a}$ \\
\hline FCM $\quad(\mathbf{k g})$ & $8.63 \square 0.19^{b}$ & $10.20 \square 0.24^{a}$ & $9.40 \square 0.22^{a}$ \\
\hline$(\%)$ & $6.64 \square 0.43^{b}$ & $7.94 \square 0.44^{a}$ & $7.16 \square 0.35^{\mathrm{ab}}$ \\
\hline Protein & $4.15 \square 0.03^{a}$ & $4.17 \square 0.03^{a}$ & $4.18 \square 0.16^{a}$ \\
\hline SNF & $9.90 \square 0.07^{a}$ & $9.90 \square 0.10^{\mathrm{a}}$ & $9.96 \square 0.11^{a}$ \\
\hline T S & $16.53 \square 0.56^{b}$ & $17.79 \square 0.45^{\mathrm{a}}$ & $17.14 \square 0.43^{a}$ \\
\hline Ash & $0.77 \square 0.04^{a}$ & $0.76 \square 0.03^{a}$ & $0.77 \square 0.03^{a}$ \\
\hline
\end{tabular}

$a$ and $b$ means in the same row followed by different letters are significantly different $(p<0.05)$.

Table (5): Fatty acids composition of buffaloes fat milk as affected by supplementation of protected and unprotected fat in the ration.

\begin{tabular}{|c|c|c|c|c|}
\hline Treat & CG & G2 & G3 & Sig. \\
\hline C6"Caproic acid" & $0.81 \pm 0.12$ & $0.89 \pm 0.08$ & $0.78 \pm 0.13$ & Ns \\
\hline C8"Caprylic acid" & $1.61 \pm 0.12$ & $1.61 \pm 0.09$ & $1.93 \pm 0.23$ & Ns \\
\hline C10"Capric acid" & $3.06 \pm 0.18$ & $3.09 \pm 0.16$ & $3.79 \pm 0.32$ & Ns \\
\hline C12"Lauric acid" & $6.31 \pm 0.65^{*}$ & $3.15 \pm 0.20$ & $4.19 \pm 0.65$ & ${ }^{*}$ con \\
\hline C14"Myristic acid" & $14.33 \pm 0.45^{\star}$ & $10.59 \pm 0.47$ & $13.98 \pm 0.16$ & ${ }^{*}$ con \\
\hline C15"Caprylic acid" & $2.65 \pm 0.25$ & $2.25 \pm 0.36$ & $2.20 \pm 0.17$ & Ns \\
\hline UN & $1.98 \pm 0.16$ & $1.77 \pm 0.11$ & $1.95 \pm 0.07$ & Ns \\
\hline C16"Palmitic acid" & $26.98 \pm 0.94$ & $26.86 \pm 0.51$ & $25.98 \pm 0.77$ & Ns \\
\hline C16.1"Palmitoleic acid" & $1.68 \pm 0.19$ & $1.63 \pm 0.29$ & $1.27 \pm 0.09$ & Ns \\
\hline C18"Stearic acid" & $11.15 \pm 0.96$ & $13.53 \pm 0.99^{*}$ & $13.11 \pm 1.18$ & ${ }^{*}$ mega fat \\
\hline C18.1"Oleic acid" & $24.42 \pm 1.08$ & $28.61 \pm 0.88^{*}$ & $25.25 \pm 1.25$ & ${ }^{*}$ mega fat \\
\hline C18.2"Linoleic acid" & $3.07 \pm 0.40$ & $3.77 \pm 0.48$ & $3.94 \pm 0.28$ & Ns \\
\hline C20"Arachinic acid" & $1.37 \pm 0.21$ & $2.34 \pm 0.78^{*}$ & $1.42 \pm 0.29$ & ${ }^{*}$ mega fat \\
\hline Total & 9942 & 100 & 9979 & \\
\hline
\end{tabular}

The fatty acid composition of the milk fat in the control and fat supplemented buffaloes was nearly similar. Table 5 . The control group showed a significant $\mathrm{P}<0.05)$ increase in both $\mathrm{C} 12$ "Lauric acid" and C14 "Myristic acid" fatty acids, as compared with the two other groups. On the other hand, Alfa-mega fat treated group resulted in a significant $(P<0.05)$ increase in C18 "stearic acid", C18-1 "oleic acid" and C20 "arachinic acid" fatty acids, as compared with the two treatments. Table 5. Unprotected, unsaturated fatty acids (FA) can be toxic to the rumen microbes unless 
saturated by microbial hydrogenation (Harfoot, 1981). Another possibility is the use of calcium salts of long-chain FA. The calcium salts are insoluble at ruminal $\mathrm{pH}$ higher 6 and have thus little effect on microbial fermentation However, the rumen-protected fats have to be highly digestible in the postruminal tract (Voigt, et al. 2006). These are the characters came in agreement with Alfa-mega fat, which contains palmitic and oleic fatty acids. Sollberger and Jans (1997) wrote in his article the quality of cheese depends on cow feds. The quality is better during summer than winter, because in the summer type of feed the oleic fatty acid (18:1) content in milk and then in cheese is higher and the cheese has softer consistence. This explains the high quality of milk produced from diets containing protected fat (Alfa Megafat) as it contains $\mathrm{C} 18, \mathrm{C} 18: 1$ and $\mathrm{C} 20$, which improve the dairy products made of such milk. Table 5 .

Production efficiency:

Results regarding body weight $(\mathrm{Kg})$, total $S V_{\mathrm{M}+\mathrm{P}}(\mathrm{Kg})$ intake $(\mathrm{Kg})$ and $S V_{P}(\mathrm{Kg})$ for milk of buffaloes cows G1, G2 and CG are represented in Table (6). Results indicated that neither body weight nor total $S V_{M+P}(K g)$ intake and $S V_{P}(\mathrm{Kg})$ for milk was non significantly between the trial groups. Considering, the production efficiency in term of $1 \mathrm{~kg} 7 \% \mathrm{FCM} / \mathrm{Kg} \mathrm{SV} \mathrm{M}_{+}$and $1 \mathrm{~kg} 7 \%$ $\mathrm{FCM} / \mathrm{Kg} \mathrm{SV}$ for milk, results indicated that the values of $1 \mathrm{Kg} 7 \% \mathrm{FCM} / \mathrm{Kg}$ $S V_{M+P}$ of buffaloes ( fed $600 \mathrm{gm}$ Alpha Mega-fat) were $(1.31 \pm 0.10) \mathrm{Kg}$ and $(1.27 \pm 0.04) \mathrm{Kg}$ of animals supplemented with $600 \mathrm{gm}$ soybean oil. While, the same parameters decreased to $(1.11 \pm 0.09)$ in control. $7 \% \mathrm{FCM} / \mathrm{Kg} \mathrm{SV}$ for milk, data showed that, the corresponding value of production efficiency increased to be $(2.85 \pm 0.02)$ for animals fed $600 \mathrm{gm}$ Alpha Mega-fat and $(2.79 \pm 0.02) \mathrm{kg}$ of buffaloes supplemented with $600 \mathrm{gm}$ soybean oil when compared with the control group. There is significant $(p<0.05)$ decrease in feed conversion in term of $(\mathrm{Kg}) 7 \% \mathrm{FCM} / 1 \mathrm{Kg}$ SV and $(\mathrm{Kg}) 7 \% \mathrm{FCM} / \mathrm{SV}$ for milk in Alpha Mega-fat and soybean oil supplementations when compared with the control. Considering the feed conversion of buffaloes cows as supplemented by Alpha Mega-fat, results revealed that value of $1 \mathrm{Kg} 7 \% \mathrm{FCM}$ $/ 1 \mathrm{Kg} \mathrm{SV}(0.75+0.03)$ and $(0.76+0.03)$ of animals supplemented $600 \mathrm{gm}$ soybean oil, respectively, as compared with the control $(0.90+0.05)$. In addition, $\mathrm{Kg} 7 \% \mathrm{FCM} / 1 \mathrm{KgSV}$ for milk, Alpha Mega-fat and soybean oil supplemented rations decreased $(P<0.05)$ significantly $(0.34+0.01)$ and $(0.35+0.01)$ of animals supplemented $600 \mathrm{gm}$ soybean oil, respectively, as compared with the control $(0.39+0.01)$. Our results came in agreement with those reported by (Palmquist, 1988). The inclusion of fat in the diet will increase energy density and, therefore, energy intake if dry matter intake (DMI) and ruminal digestion are not affected by fat supplementation. The inclusion of fat supplements in total mixed rations (TMR) has been associated with a reduction in DMI and as a consequence, only a moderate increase in total energy intake (5-6\%) may be expected (Palmquist, 1984; Gagliostro and Chilliard, 1992; Chilliard, 1993). The reduction in DMI has been highly associated with the source and amount of fat supplement used (Coppock et al., 1987; Gagliostro and Chilliard, 1992; Wu and Huber, 1994). One of the limitations on the use of fat supplements to ruminants has been the potential negative effects on fiber digestion in the rumen (Palmquist, 1984; Jenkins, 
1993). These deleterious effects have been associated with an inhibition on microbial activity, particularly that of cellulolitic and methanogenic microorganisms (Palmquist, 1984). These effects could be due to a direct action of the FA on the cellular membrane of the microorganisms and/or due to indirect effects by a reduction in the ruminal availability of cations such as calcium and magnesium (Palmquist, 1988; Jenkins, 1993). The negative effects increased with the degree of solubility of fat sources, being highest with medium and long-chain FA and with unsaturated FA (Jenkins, 1993). Although, the differences between means of (G2 \& G3) for both parameters (production efficiency and feed conversion) in buffaloes were not significant; it is economically to use $600 \mathrm{gm}$ of Alpha Mega-fat instead of $600 \mathrm{gm} /$ soybean oil /head/day in rations of lactating animals on basis of milk data analysis. These results are in agreement with those reported by Sanz Sampelayo et al. (2004) and Lubis et al. (1990).

Tables (6): Milk production efficiency in buffaloes as by supplementation of protected and unprotected fat in the ration.

\begin{tabular}{|c|c|c|c|}
\hline Item & CG & G2 & G3 \\
\hline Body weight & $563 \square 19.83^{\mathrm{a}}$ & $565 \square 18.91^{a}$ & $562 \square 19.75^{a}$ \\
\hline Total SV $\mathrm{M}_{\mathrm{M}+\mathrm{P}^{*}}$ intake $(\mathrm{kg})$ & $5.11 \square 0.12^{\mathrm{a}}$ & $5.31 \square 0.64^{\mathrm{a}}$ & $5.32 \square 0.14^{\mathrm{a}}$ \\
\hline $\mathrm{SV}_{\mathrm{P}}$ intake $(\mathrm{kg})$ for milk & $2.19 \square 0.07^{a}$ & $2.43 \square 0.08^{\mathrm{a}}$ & $2.45 \square 0.40^{\mathrm{a}}$ \\
\hline Average 7\% FCM (kg) / day. & $8.63 \square 0.19^{b}$ & $10.20 \square 0.24^{\mathrm{a}}$ & $9.40 \square 0.22^{\mathrm{a}}$ \\
\hline Feed conversion: & & & \\
\hline $\begin{array}{l}(\mathrm{kg}) 7 \% \mathrm{FCM} / 1 \mathrm{~kg} \mathrm{SV} \mathrm{M}+\mathrm{p}^{*} \\
\left(\mathrm{~kg} \% \% \mathrm{FCM} / 1 \mathrm{~kg} \mathrm{SV} \mathrm{P}_{\mathrm{p}} \text { for milk }\right.\end{array}$ & $\begin{array}{l}0.90 \square 0.05^{a} \\
0.39 \square 0.01^{a}\end{array}$ & $\begin{array}{l}0.75 \square 0.03^{\mathrm{b}} \\
0.34 \square 0.01^{\mathrm{b}}\end{array}$ & $\begin{array}{l}0.76 \square 0.03^{\mathrm{b}} \\
0.35 \square 0.01^{\mathrm{b}}\end{array}$ \\
\hline $\begin{array}{c}\text { Production efficiency: } \\
\text { (kg)7\%FCM/1kg SV M + P } \\
\text { (kg)7\% FCM /1kgSVP for milk }\end{array}$ & $\begin{array}{l}1.11 \square 0.09^{b} \\
2.56 \square 0.02^{b}\end{array}$ & $\begin{array}{l}1.31 \square 0.10^{\mathrm{a}} \\
2.85 \square 0.02^{\mathrm{a}}\end{array}$ & $\begin{array}{l}1.27 \square 0.04^{\mathrm{a}} \\
2.79 \square 0.02^{\mathrm{a}}\end{array}$ \\
\hline
\end{tabular}

$a$ and $b$ means in the same row followed by different letters are significantly different $(p<0.05)$.

\section{REFERENCES}

Agriculture economic institute (1997). Ministry of agriculture; Dokki; Egypt; in Arabic.

"A.O.A.C" Association of Official Agriculture Chemists, (1990). Official Methods of Analysis. 10 th Ed. Published by the A. O. A. C., Washington, D. C., USA.

AOAC. Official Methods of Analysis (2000). 17 Ed.. Gaithersburg; MD.

Bargo, F., Muller, L.D., Kolver, E.S., Delahoy, J.E.( 2003): Invited review: Production and digestion of supplemented dairy cows on pasture. J. Dairy Sci. 86, $1-42$.

British Standards Institution (1962). British Standard methods for dertermination of milk fat the Gerber method. bull, P. 962.

Chilliard, Y., (1993): Dietary fat and adipose tissue metabolism in ruminants, pigs, and rodents: A review. J. Dairy Sci. 76, 3897-3931. 
Coppock, C.E., Lanham, J.K., Horner, J.L.,( 1987): A review of nutritive value and utilization of whole cottonseed, cottonseed meal, and associated by-products by dairy cattle. Anim. Feed Sci. Technol. 18, 89-97.

Davison, T.M., Vervoort, F.P., Duncalfe, F., (1991): Responses to a longchain fatty acid supplement fed to dairy cows at two stages of lactation. Aust. J. Exp. Agric. 31, 467- 470.

Doreau, M. and Ferlay, A. (1995): Effect of dietary lipids on nitrogen metabolism in the lumen: a review. Livestock Production Science 43 ( 1995) 97-I 10.

F.A.O.(1979). The composition of ewe,s and goat,s milk. Production yearbook, vol. $33(5)$.

Gains, W. L. (1928). An efficiency formula for dairy cows. Science, $67: 353$.

Gagliostro, G.A., Chilliard, Y., (1992): Utilizacio'n de lı'pidos protegidos en la nutricio'n de vacas lecheras. I. Efectos sobre la produccio 'n y la composicio'n de la leche, y sobre la ingestio'n de materia seca y energı'a. Rev. Arg. Prod. Anim. 12 (1), 1 - 15.

Garnsworthy, P.C.(1997): Fats in dairy cow diets. In: Garnsworthy, P.C., Cole, D.J.A. (Eds.), Recent Advances in Animal Nutrition, pp. 87-103 University of Nottingham.

Hamzawi, L. F. and Y. Shahin (1986) : Fatty acid composition of milk fat globule membrane phospholipids from verious species. Milchwisson shaft, $41: 754$.

Harfoot, C.G., (1981): Lipid metabolism in the rumen. In: Lipid metabolism in ruminant animals, Ed. Christie et al., Pergamon Press, Oxford, UK, p. 21-55

Helal, F.I.S and. Lasheen M.A (2008) : The Productive Perforance of Egyptian Dairy Buffaloes Receiving Biosynthetic Bovine Somatotropin (rbST) with or Without Monensin. American-Eurasian J. Agric. \& Environ. Sci., 3 (5): 771-777.

Jenkins, T.C., (1993): Lipid metabolism in the rumen. J. Dairy Sci. 76, 38513863.

Kononoff, P. J. ; Jeffrey F. K., and Richard J. G., (2005): Supplemental Fat For High-Producing Dairy Cows. G1581, Index: Dairy Feeding \& Nutrition Issued October 2005.

Lubis, D. H. H. Van Horn, Harris, JR., K. Bachman, and Emanuel E. M. (1990). Responses of Lactating Dairy Cows to Protected Fats or Whole Cottonseed in Low or High Forage Diets', Journal of Dairy Science Vol. 73. No. 12.

Mattos, W. and Palmquist, D. L. (1974) : Increased Polyunsaturated Fatty Acid Yields In Milk of Cows Fed Protected Fat. Journal of Dairy Science VOL. 57. No. $9: 1050-1054$.

Oser, L. B. (1965) : Howks physiological chemistry, McGrow - Hill Book Co., New York and London, $14^{\text {th }}$ Ed. Pp. $390-391$.

Palmquist, D.L. (1984) : Use of fats in diets for lactating dairy cow. Fat in Animal Nutrition, pp. 357-381 Editions Bultersworkts, London.

Palmquist, D.L. (1988): The feeding value of fat. In: Orskov, E.R. (Ed.), Feed Science, pp. 293-311 Elsevier, Amsterdam. 
Parodi, P.W. (1999): Conjugated linoleic acid and other anticarcinogenic agents of bovine milk fat. J. Dairy Sci. 82, 1339-1349.

Raafat, M. A. and Saleh, M. S. (1962). Two formulas for conversion of cows and buffaloeses milk of different fat percentage into milk standard fat percentage, preceding of the $1^{\text {st }}$ Anim. Prod. conference at Minia, $\mathrm{P}$ 203.

Sanz Sampelayo M. R., Martı́n Alonso J. J., Pe' rez L., Gil Extremera F., and Boza J., (2004). Dietary Supplements for Lactating Goats by Polyunsaturated Fatty Acid-Rich Protected Fat. Effects After Supplement Withdrawal. Journal of Dairy Science Vol. 87, No. 6, 2004.

S.A.S. (1998).Statistical Analysis System User, Quide: Basis. SAS Inst. Inc Cary. NC

Schroeder, G.F., Gagliostro, G.A., Becu-Villalobos, D., Lacau- Mengido, I.(2002): Supplementation with partially hydrogenated oil in grazing dairy cows in early lactation. J. Dairy Sci. 85, 580- 594.

Schroeder G.F., Gagliostro G.A., Bargo F., Delahoy J.E., Muller L.D.,(2004): Effects of fat supplementation on milk production and composition by dairy cows on pasture: a review, Livest. Prod. Sci. 86 (2004) 1-18.

Scott, T. W.;Cook, L. J. ; Ferguson, K. A. ; McDonald, I. W. ; Buchanan, R. A. and Loftus Hills G. (1970): Production of polyunsaturated milk fat in domestic ruminants. Austral. J. Sci. 32:291.

Scott, T. W.;Cook, L. J. and Mills S. C. (1971): Protection of dietary polyunsaturated fatty acids against microbial hydrogenation in ruminants. J. Amer. Oil Chem. Soc. 48: 358.

Skaar, T.C., Grummer, R.R., Dentine, M.R., Stauffacher, R.H., (1989): Seasonal effects of prepartum and postpartum fat and niacin feeding on lactation performance and lipid metabolism. J. Dairy Sci. 72, 20282038.

Sollberger, H. and Jans, F. (1997): die winterfueturung und die emmentalerqualitat. Schweizerischemilchzeitung, 49, 9.

Voigt, J. ; Kuhla $\square$, S.; Gaafar, K.; Derno, M. and Hagemeister, H. (2006): Digestibility of rumen protected fat in cattle. Slovak J. Anim. Sci., 39, $2006(1-2): 16-19$

Wu, Z., Huber, J.T., (1994): Relationship between dietary fat supplementation and milk protein concentration in lactating cows: A review. Livest. Prod. Sci. 39, 141- 155. 
"تأثير إضـافة الدهن المحمي والدهن الغير المحمي علي إنتاج اللبن وتركيبه في

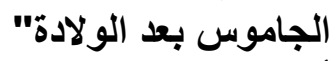

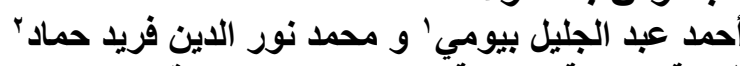

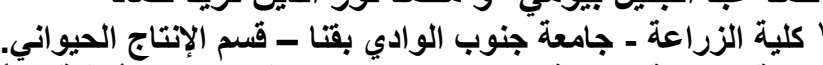

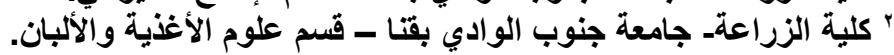

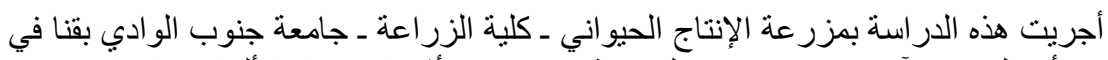

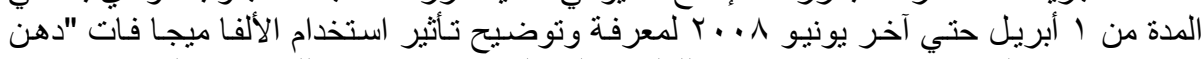

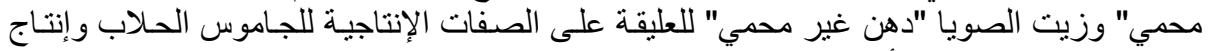

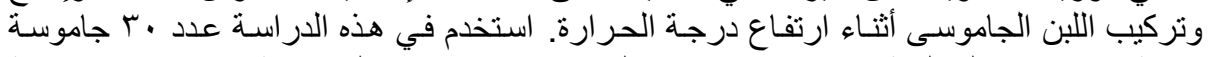

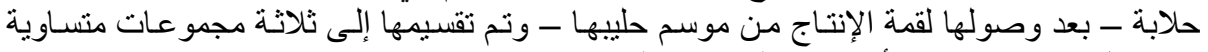

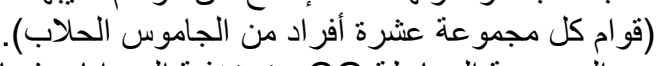

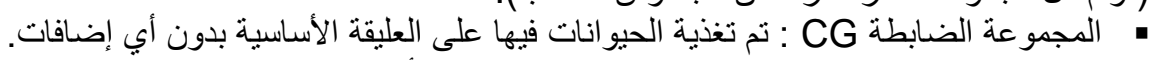

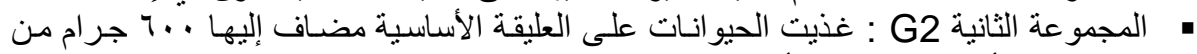

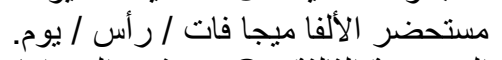

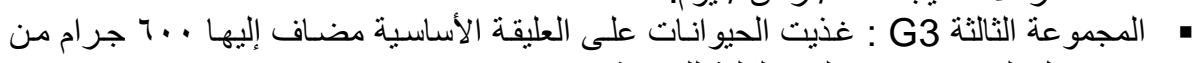

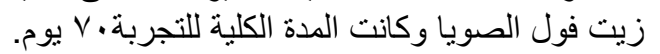

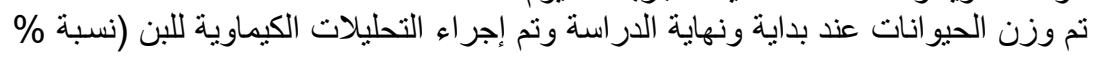

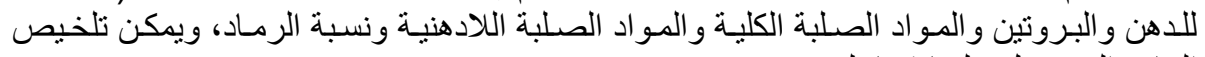

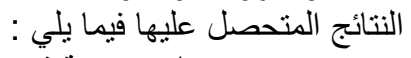

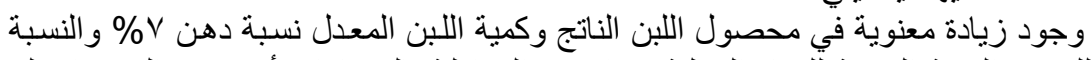

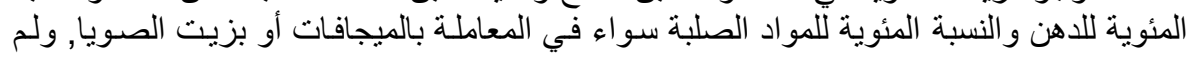

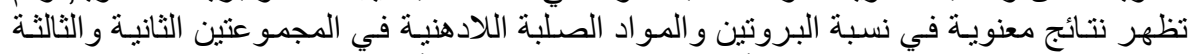

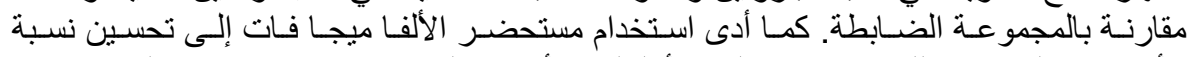

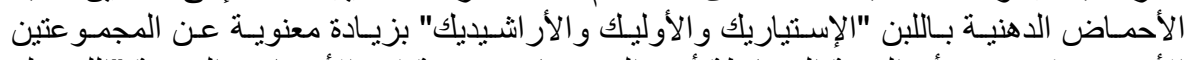

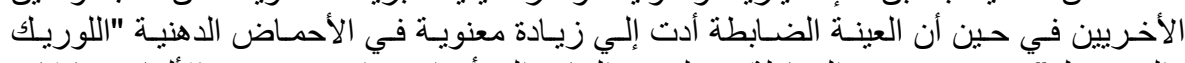

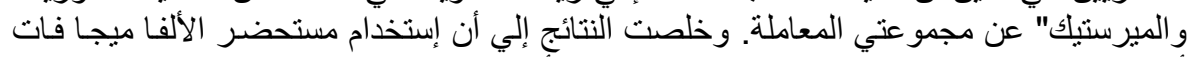

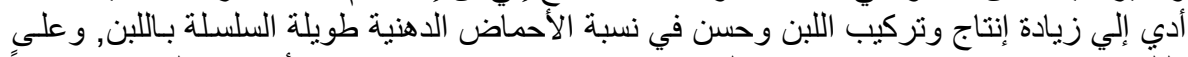

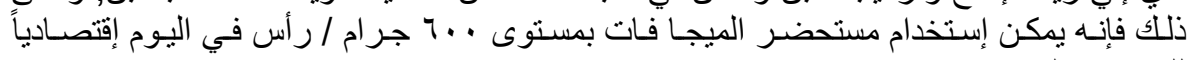

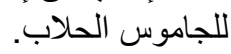

